ECONOMICS IN HORTICULTURE 
Some other ELBS low-priced editions

\begin{tabular}{|c|c|c|}
\hline $\begin{array}{l}\text { Bridger and } \\
\text { de Soissons }\end{array}$ & FAMINE IN RETREAT? & Dent \\
\hline $\begin{array}{l}\text { Chapman and } \\
\text { Chapman }\end{array}$ & THE ALGAE & Macmillan \\
\hline $\begin{array}{l}\text { Cobley and } \\
\text { Steele }\end{array}$ & $\begin{array}{l}\text { AN INTRODUCTION TO THE } \\
\text { BOTANY OF TROPICAL CROPS }\end{array}$ & Longman \\
\hline Cooke & $\begin{array}{l}\text { FERTILIZING FOR MAXIMUM } \\
\text { YIELD }\end{array}$ & $\begin{array}{l}\text { Crosby } \\
\text { Lockwood } \\
\text { Staples }\end{array}$ \\
\hline Giles & MARKETING & $\begin{array}{l}\text { Macdonald \& } \\
\text { Evans }\end{array}$ \\
\hline Hanson & $\begin{array}{l}\text { A DICTIONARY OF ECONOMICS } \\
\text { AND COMMERCE }\end{array}$ & $\begin{array}{l}\text { Macdonald \& } \\
\text { Evans }\end{array}$ \\
\hline Lipsey & $\begin{array}{l}\text { AN INTRODUCTION TO POSITIVE } \\
\text { ECONOMICS }\end{array}$ & Weidenfeld \\
\hline $\begin{array}{l}\text { Marshall and } \\
\text { Williams }\end{array}$ & $\begin{array}{l}\text { A TEXTBOOK OF ZOOLOGY: VOL. I } \\
\text { INVERTEBRATES }\end{array}$ & Macmillan \\
\hline $\begin{array}{l}\text { Paish and } \\
\text { Culyer }\end{array}$ & BENHAM'S ECONOMICS & Pitman \\
\hline $\begin{array}{l}\text { Parker and } \\
\text { Haswell }\end{array}$ & $\begin{array}{l}\text { A TEXTBOOK OF ZOOLOGY: VOL. II } \\
\text { VERTEBRATES }\end{array}$ & Macmillan \\
\hline Purseglove & $\begin{array}{l}\text { TROPICAL CROPS - } \\
\text { DICOTYLEDONS }\end{array}$ & Longman \\
\hline Purseglove & $\begin{array}{l}\text { TROPICAL CROPS - } \\
\text { MONOCOTYLEDONS }\end{array}$ & Longman \\
\hline Russell & $\begin{array}{l}\text { SOIL CONDITIONS AND PLANT } \\
\text { GROWTH }\end{array}$ & Longman \\
\hline $\begin{array}{l}\text { Webster and } \\
\text { Wilson }\end{array}$ & AGRICULTURE IN THE TROPICS & Longman \\
\hline Wheeler & $\begin{array}{l}\text { AN INTRODUCTION TO PLANT } \\
\text { DISEASES }\end{array}$ & $\begin{array}{l}\text { John Wiley, } \\
\text { London }\end{array}$ \\
\hline $\begin{array}{l}\text { Williamson } \\
\text { and Payne }\end{array}$ & $\begin{array}{l}\text { AN INTRODUCTION TO ANIMAL } \\
\text { HUSBANDRY IN THE TROPICS }\end{array}$ & Longman \\
\hline
\end{tabular}




\section{Science in Horticulture Series}

General Editor: Professor L. Broadbent, University of Bath

Published in collaboration with the Royal Horticultural Society and the Horticultural Education Association.

This series of texts has been designed for students on courses in horticulture at the Higher National Certificate or Diploma level, but care has been taken to ensure that they are neither too specialised for lower-level courses, nor too superficial for university work.

All the contributors to the series have had experience in both the horticultural industry and education. Consequently, the books have a strong practical flavour which should reinforce their value as textbooks and also make them of interest to a wide audience, including growers and farmers, extension officers, research workers and workers in the agrochemical, marketing and allied industries, and the many gardeners who are interested in the science behind their hobby.

The authors are all British but they have illustrated their books with examples drawn from many countries. As a result the texts should be of value to English-speaking students of horticulture throughout the world. 


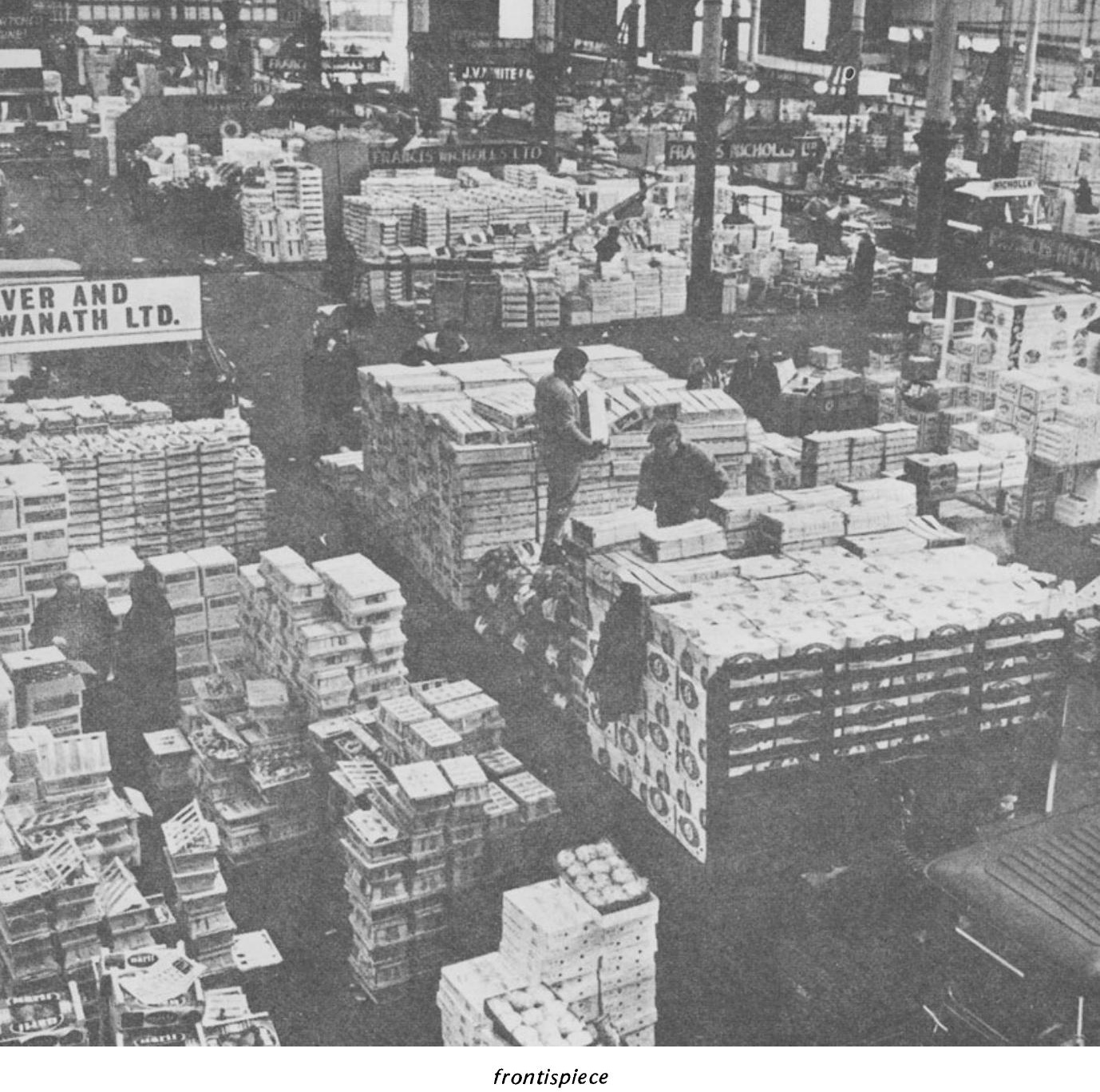




\title{
ECONOMICS IN HORTICULTURE
}

\author{
M. J. Sargent \\ Lecturer in Horticulture, University of Bath
}

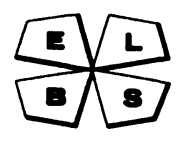

ENGLISH LANGUAGE BOOK SOCIETY

and

MACMILLAN EDUCATION 
Produced in collaboration with the Horticultural Education Association and the Royal Horticultural Society

(C) M. J. Sargent 1973

All rights reserved. No part of this publication may be reproduced or transmitted, in any form or by any means, without permission

ELBS edition first published 1978

First published 1973 by

THE MACMILLAN PRESS LTD

London and Basingstoke

Associated companies in Delhi

Hong Kong Lagos and Singapore

\section{ISBN 978-0-333-24630-6 ISBN 978-1-349-04111-4 (eBook) \\ DOI 10.1007/978-1-349-04111-4}

Set I.B.M. by

GEORGE OVER LIMITED, LONDON AND RUGBY

The paperback edition of this book is sold subject to the condition that it shall not, by way of trade or otherwise, be lent, re-sold, hired out, or otherwise circulated without the publisher's prior consent in any form of binding or cover other than that in which it is published and without a similar condition including this condition being imposed on the subsequent purchaser. 


\section{CONTENTS}

Acknowledgements viii

Introduction ix

1 THE NATIONAL ECONOMY 1

1.1 The Gross National Product 1

1.2 Agriculture and economic growth 3

1.3 Case study illustrations of hortculture in the national economy $\quad 7$

2 PRICE 16

$\begin{array}{lll}2.1 & \text { Demand } & 18\end{array}$

$\begin{array}{lll}2.2 & \text { Supply } & 29\end{array}$

2.3 Interaction of demand and supply 31

3 MARKETING 36

3.1 The markets 42

3.2 Grower organisations 46

$\begin{array}{lll}3.3 & \text { Retailing } & 49\end{array}$

4 PRODUCTION 53

4.1 The firm 53

4.2 Input output relationships 55

$\begin{array}{lll}4.3 & \text { Risk and uncertainty } & 62\end{array}$

5 RESOURCES $\quad 69$

$\begin{array}{lll}5.1 & \text { Capital } & 69\end{array}$

$\begin{array}{ll}5.2 \text { Land } & 77\end{array}$

$\begin{array}{ll}5.3 \text { Labour } & 81\end{array}$

6 ORGANISING PRODUCTION 87

$\begin{array}{lll}6.1 & \text { The behaviour of costs } & 87\end{array}$

6.2 Determining the quantity of resources to use 93

6.3 Determining which product or crop to grow 99

$\begin{array}{ll}6.4 & \text { Planning techniques } \\ & 101\end{array}$

$\begin{array}{ll}7 \text { LOCATION } & 106\end{array}$

$\begin{array}{lll}7.1 & \text { Intranational trade } & 106\end{array}$

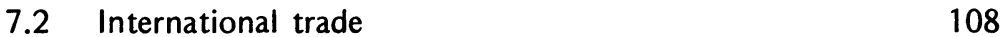

$\begin{array}{ll}7.3 \text { Case studies of location } & 113\end{array}$

8 POLICY 118

$\begin{array}{lll}8.1 & \text { Producer incomes } & 118\end{array}$

$\begin{array}{ll}\text { 8.2 The mechanisms of government policies } & 121\end{array}$

$\begin{array}{ll}\text { 8.3 Case studies of horticultural policy } & 124\end{array}$

$\begin{array}{ll}\text { Appendixes } & 129\end{array}$

$\begin{array}{ll}\text { Further reading } & 131\end{array}$

$\begin{array}{ll}\text { Index } & 133\end{array}$ 


\section{ACKNOWLEDGEMENTS}

This book is the product of experience with growers, economists and more recently with university students of horticulture. Their stimulation and encouragement is gratefully acknowledged.

I am particularly indebted to Professor Leonard Broadbent, whose helpful suggestions and skilful editing, have greatly improved the readability of the final product. I would also like to thank my other colleagues at Bath for their encouragement and helpful comments on early drafts.

The assistance is also gratefully acknowledged of workers and organisations who have allowed me to reproduce tabular material to give the text greater realism. In particular the Publicity Department of the Francis Nicholls Organisation, Smithfield Market, Birmingham, who provided the frontispiece. The permission of the Controller of Her Majesty's Stationery Office has been obtained for the use of certain tables.

Finally, I am deeply indebted to my wife, Valerie, who not only had to endure many lonely evenings during the preparation of the book but has also helped by reading early drafts and proofs. 


\section{INTRODUCTION}

The word economy has two Greek roots referring to household or estate management. Economics has been generally in use only since the early part of this century. In more recent years it has broadened in scope and today encompasses many specialist disciplines. Economics is concerned with the exchange of goods and services between people and the organisation of scarce resources. This definition clearly needs elaboration.

Returning to the older household management root can provide us with a very simplified example. The urban housewife of today has a limited income to spend organising her budget so that the family is fed, clothed and maintained. She allocates her scarce resources between these competitive uses of her money to gain the greatest satisfaction possible. Food and heating may well have priorities and thereafter she may have a scale of preferences towards the more luxury types of consumption such as recreation and holidays. In just the same way as she allocates her scarce resources so does the Government in organising its annual budget and so does the horticultural producer in organising his spending. Our housewife may gain satisfaction from her spending by the sight of a happy contented family. Benefits accruing from Government expenditure are much more intangible and difficult to quantify. The grower has more positive benefits in terms of moneys coming from the sale of produce in a market. This is his source of moneys for further expenditure and his own family maintenance. The Government may raise its moneys by taxation on land, imports and incomes of the population. Our housewife's income will have been derived from her own or her husband's work. In reality of course the husband might be employed by the Government as a civil servant. He may pay taxes to the Government on his income. His wife may buy produce from the grower, who in turn is also a consumer and taxpayer, but in addition may well receive assistance from Government expenditure.

\section{Exchange}

In our example we can identify logically and conveniently distinct parts of the exchange economy. The grower is concerned with production of crops using the resources of land, capital and labour. In the exchange economy he sends his produce to consumers, many living in urban centres geographically removed from his holding. The process of transferring products from the point of production to the consumer is called marketing. The grower's organisation of production and marketing, usually with profits as a goal, is called management. Central Government 
concerned with the smooth running and strength of the national economy may need to influence this exchange system to improve its overall efficiency. It may for example introduce a wage restraint or income tax in order to manipulate consumers' incomes; the grower may receive grant aid or tax concessions and by these means a national policy is adopted towards a particular economic end. Stimulation of exports, retarding of imports, expansion of particular forms of production or consumption may be chosen. The professional economist is concerned with the efficient use of resources at individual, business and national level; as an observer of consumer and producer activities and of the effects of Government policies he carries out an economic analysis. He may construct simple graphic or more complex mathematical models of particular situations from which he tries to understand past situations and to predict with reasonable certainty future results from given actions.

Money is the basis and common exchange medium in our example and it is in markets that this exchange occurs. It is here that consumers make their desires known and values are determined for the goods or services exchanged. Even in our very simple example there are clearly many more people involved than the three central figures. The whole population of the country and if international trading is included, of the world, are involved in economic exchange. Man is a social animal and society comprises a wide genetic spectrum of races and of behavioural pattern to given stimuli. Economics is concerned with the behaviour of people in allocating their scarce resources - it is a social science.

\section{Economics and social sciences}

The social sciences include such disciplines as sociology, anthropology, geography and psychology; subjects less familiar to the student of horticulture who more commonly finds himself associated with the natural sciences. This is particularly true of the horticultural colleges and university departments. In common with all sciences measurement features prominently in social investigations. The objects concerned in this measurement and the units used are perhaps the earliest stumbling block encountered by the student new to the subject. Once these new concepts have been mastered there are some similarities of approach to other sciences and much is common sense. One cannot do better at this stage than to quote the well known economist Colin Clark who in a recent book called Starvation and Plenty says:-

'So much of economics consists of statements which are obvious as soon as one comes to look at them but which for various reasons seem to escape the notice of active statesmen and of learned professors.'

The economist in particular does face some rather different problems. It is very difficult for him to carry out a controlled experiment in the same manner as one might for example investigate the effects of temperature on photosynthesis in plant physiology. He relies on observations, theories and 
conclusions drawn from statistical records of the past. Value judgements inevitably feature prominently. The student must learn early on to distinguish between fact and opinion and appraise them in relation to the current state of knowledge. As a young subject its theories are not highly developed and capable of proof; mathematical tools as aids to the expression of new concepts are a comparatively recent addition.

A student new to economics will soon discover that it is an opinionated subject. Everyone knows something about money, trade, taxation and will offer advice to the exchequer on the running of the economy. Even professional economists disagree on their methods of analysis and interpretations of situations. There is an old joke, often attributed to Keynes, that if you take any six economists you have seven opinions. Inevitably perhaps there may commonly be a large gap between theoretical analysis and reality. Having to live through the implementation of a treatment prescribed by an economist has been an unhappy experience for more than one individual.

\section{Agricultural economics and horticulture}

Agricultural economics has evolved as a separate study largely within this century. This has probably come about because its origins were often in institutions concerned with husbandry aspects of agriculture. The study of the business management aspects of these husbandries has gradually led to deeper investigations of the economics of agriculture. Today agricultural economics has its own learned societies nationally and internationally and is an established discipline in universities.

Studies of the economics of horticulture have always been regarded in the past as simply part of agricultural economics. Often horticulture has found itself something of a 'cinderella' in this respect. The producers of goods for relatively luxury consumption, such as flowers, fruits and vegetables, have not commanded the same attention as producers of bulk carbohydrates and more recently animal proteins. Not surprisingly this is reflected in a dearth of statistical and documented information about many horticultural crops and situations. In the past twenty years however there has been some improvement in the situation and one of the most encouraging signs has been the establishment of a clearly viable sub-group of the International Society for Horticultural Science to study horticultural economics.

\section{Horticulture defined}

In lecturing to his own students the author defines horticulture as that part of agriculture concerned with the production of relatively high value crops, not including those for bulk carbohydrate production or the extraction of chemicals or for animal production. This is a negative definition in that it delineates a residue of crops relevant to United Kingdom horticulture. In another climate other crops may be regarded as 
horticultural and others seen as simply part of agriculture. Even in the UK vegetable crops and even nursery stock are being grown to an increasing extent on large farms having agricultural crops as well in terms of the definition above. Fruit growing has always featured in mixed farm cropping. In these situations the economist cannot escape consideration of agricultural crops if he is investigating the business economy.

A further problem of the use of the word horticulture is its equation in the minds of many of the general public with gardening. Horticulture is a sophisticated technology and education of the general public to this effect is still necessary. It is a professional and commercial, not amateur, occupation and in this book as the title implies we are concerned solely with commercial horticulture.

Even commercial horticulture today can be sub-divided into specialist disciplines. The two broad categories of crop production and amenity (including nursery stock) are usually recognised. The latter category is different in that it is concerned with creating an effect. A display or amenity planting is only achieved at cost and it may even help to 'sell' a resort or town to tourists but it is not sold itself. Nursery stock production is a unique area of horticulture as well. Although its products are marketed they are not sold in the same manner as most fruit, vegetables and flowers. Most nursery stock producers are able to determine the price of their products themselves. This does not mean that they can charge what they like because they are still in competition with other nursery stock producers. In this respect they are more akin to producers in other non-agricultural industries.

This book is concerned with economics in commercial crop production. It may be that we need a new word to describe this type of horticulture but any new word would have to achieve international acceptance.

\section{Economics in horticulture}

Horticultural technology is related to many other disciplines of both the arts and sciences. Economics with its roots in the social sciences broadens its outlook considerably for it is truly inter-disciplinary and international. Furthermore the comparative youth of horticultural economics as a study means that it is still possible to achieve originality from seemingly quite elementary investigations.

The writer of a textbook cannot hope to mirror all the opinions of economists in an introductory text. It is intended here to lift the veil surrounding economics in horticulture. It is hoped that the reader or student or grower or adviser or even other economists might find encouragement to delve further into the literature of general economics. It can only be beneficial for horticulturists to become more familiar with the social sciences and for them to try to understand the particular characteristics of the industry. A reference list for suggested further 
reading is included at the end of this book. It must be stressed however that economics is a dynamic science. The economic situation is undergoing continual change. The serious student should try to relate daily news bulletins and their contents to his knowledge of economics.

Ideally this broad spectrum subject ought to be read with the chapters in parallel. Inevitably however one chapter has to follow another: the cyclic arrangement of chapter headings seemed to the author the next best solution. Thus we start with the overall national economy and conclude at national level again in considering governmental policies. In between we gradually focus down on the individual grower and his business. 